\title{
On the Mourning Customs of Elephants
}

Elephants are mediocre escape artists. True, they visit the dead body after it has decayed. And as they stand there, they undoubtedly ask themselves: How is this elephant different from other elephants? Did he do something noteworthy with his life? Why shall we not forget this one?

One of the elephants says: Maybe, when he was in captivity, he visited thirty different cities. And another, very old elephant adds: Maybe, fleeing from humans, he walked two hundred miles in a single night. And then they all remember, with a gentle smile: The road home was fraught with danger. The ocean waves were high. When he jumped from the deck a full moon floated in the sky...

Elephants believe that the idea of death is quite simple-they believe that they are always to blame. Contrary to popular belief, at the necessary moment elephants can jump a little, so that all four of their feet are in the air at once. 